\title{
APLIKASI KOMBINASI FILTER BERTINGKAT UNTUK PENGOLAHAN LIMBAH CAIR INDUSTRI TEMPE DI KELURAHAN KEKALIK JAYA KOTA MATARAM
}

\author{
Diah Ajeng Setiawati*), Guyup Mahardhian DP, Fakhrul Irfan Khalil, Wahyudi \\ Zulfikar, Hirjani \\ Program Studi Teknik Pertanian, FATEPA, Universitas Mataram \\ Jalan Majapahit Nomor 62, Mataram 83125 \\ *alamat korespondensi: diahajengs@unram.ac.id
}

\begin{abstract}
ABSTRAK
Terdapat sekitar 113 pengusaha tempe yang mengolah 20 ton kedelai per hari di daerah Kekalik Jaya, Kota Mataram. Limbah padat industri tempe berupa tangkai dan kulit kedelai selama ini dikelola dengan menjual pada pengusaha ternak sapi yang memanfaatkan limbah ini sebagai pakan ternak. Limbah cair langsung dibuang begitu saja ke badan air sungai yang terletak di daerah Kekalik. Salah satu teknologi yang dapat diaplikasikan untuk mengatasi permasalahan di atas adalah teknologi filtrasi (penyaringan). Kegiatan pengabdian kepada masyarakat ini menggunakan filter yang berisi media butiran, yaitu kombinasi arang aktif, zeolit, dakron, pasir silika dan kerikil yang disusun pada pipa wadah akrilik berukuran 15 $\mathrm{cm} \times 15 \mathrm{~cm} \times 100 \mathrm{~cm}$. Sistem filtrasi terdiri dari dua unit filtrasi untuk meningkatkan efisiensi penyisihan zat organik yang masih terkandung dalam limbah cair tempe. Pemilik usaha, para pekerja, masyarakat sekitar yang menghadiri kegiatan terlihat sangat antusias untuk menerima penyuluhan. Khususnya karena limbah yang dihasilkan cukup menggangu masyarakat akibat timbulnya bau busuk di badan air (sungai dan selokan) dan warna air menjadi semakin keruh dan menghitam. Masyarakat yang mengikuti kegiatan ini merasa optimis kualitas lingkungan dan kesehatan masyarakat akan lebih baik dengan aplikasi teknologi yang ditawarkan pada kegiatan ini. Modul filtrasi bertingkat yang diperkenalkan sebagai salah satu alternatif dalam pengolahan limbah cair tempe dalam kegiatan ini dapat mengolah limbah cair dengan baik jika kondisinya tidak terlalu pekat. Selain itu, teknologi lubang resapan biopori yang juga diperkenalkan dalam kegiatan ini dapat diaplikasikan sebagai salah satu solusi untuk pengolahan limbah padat dan cair, sekaligus mencegah genangan pada wilayah terkait, terutama saat musim hujan.
\end{abstract}

Kata kunci: filtrasi bertingkat, limbah cair, tempe 


\section{PENDAHULUAN}

Limbah adalah sisa kegiatan yang dianggap tidak lagi dapat diambil manfaatnya sehingga umumnya dibuang ke lingkungan. Setiap kegiatan manusia berpotensi menghasilkan limbah. Setiap daerah menghasilkan limbah yang spesifik dan juga sangat ditentukan oleh kegiatan usaha yang berkembang di daerah tersebut. Di Surakarta, contohnya, Sungai Jenes sangat tercemar oleh limbah cair yang dihasilkan UMKM batik (Kurniawan, dkk., 2013). Balai Lingkungan Hidup Kota Blitar mengalami kesulitan dalam mengatasi limbah yang dihasilkan pengrajin tahu tempe di Kelurahan Pakunden (Anonim, 2016). Di Mataram, indutri tempe menjadi salah satu sumber penghasil limbah yang potensial. Limbah yang dihasilkan dari industri pengolahan tempe umumnya berupa limbah padat (tangkai dan kulit kedelai) dan limbah cair (yang bersumber dari perebusan tempe).
Industri pengolahan tempe telah puluhan tahun digeluti sebagian besar warga Kekalik Jaya sebagai sumber penghasilan utama secara turun temurun. Pengolahan kedelai menjadi tempe di daerah ini masih dilakukan secara manual menggunakan teknologi sederhana. Di Kekalik Jaya, limbah padat industri tempe berupa tangkai dan kulit kedelai selama ini dikelola dengan menjual pada pengusaha ternak sapi yang memanfaatkan limbah ini sebagai pakan ternak. Sedangkan limbah cairnya tidak diolah karena kurangnya pengetahuan pengusaha tempe mengenai teknologi pengolahan limbah cair. Limbah cair yang dihasilkan langsung dibuang begitu saja ke badan air sungai yang terletak di daerah Kekalik. Berdasarkan pemaparan salah seorang pengusaha tempe di sana, limbah cair tersebut berwarna kuning keruh dan berbau tengik. Setelah disimpan dalam waktu lama, baunya akan semakin menyengat dan sangat mengganggu pernafasan. Kondisi ini menunjukkan terdapatnya 
kandungan zat organik tersuspensi dan terlarut yang tinggi pada limbah cair tempe.

Kandungan zat organik yang tinggi ini berpotensi menurunkan kualitas lingkungan jika tidak dilakukan penanganan yang serius. Dari beberapa hasil penelitian, konsentrasi COD (Chemical Oxygen Demand) dalam air limbah industri tempe cukup tinggi, berkisar 7.000 10.000 ppm, serta mempunyai keasaman yang rendah yakni $\mathrm{pH}$ 4-5 (Said dan Herlambang, 2003). Berdasarkan studi kasus yang terjadi di sekitar Sungai Code, telah ditemukan banyaknya warga yang rentan terkena penyakit serta rusaknya organisme, biota, hewan, dan tumbuhan akibat zat-zat pencemar pada badan air (Puspitasari, 2009). Hal ini menunjukkan bahwa dampak dari penurunan kualitas lingkungan ini tidak hanya akan dirasakan oleh warga sekitar pembuangan limbah di bantaran sungai saja, tetapi juga makhluk hidup lain di dalam ekosistem.
Berdasarkan latar belakang ini, tim kegiatan pengabdian kepada masyarakat tergerak untuk melakukan satu bentuk kegiatan di daerah Kekalik Jaya, khususnya untuk memberikan solusi dalam penanganan limbah cair yang dihasilkan dari kegiatan pengolahan kedelai menjadi tempe. Tujuan kegiatan pengabdian kepada masyarakat ini adalah:

a. Memberikan edukasi pada para pengusaha tempe tentang pentingnya pengelolaan limbah industri pangan, khususnya limbah cair industri tempe

b. Memperkenalkan teknologi sederhana berupa filter bertingkat yang dapat mengurangi kandungan zat organik pada limbah cair tempe.

\section{METODE KEGIATAN}

Kegiatan pengabdian kepada masyarakat ini telah dilaksanakan pada bulan September 2018 yang menyasar pelaku usaha kecil pengrajin tempe di wilayah Kelurahan 
Kekalik Jaya, Kecamatan Sekarbela, Mataram.

Alat yang digunakan dalam program pengabdian kepada masyarakat ini adalah: Modul filtrasi bertingkat, wadah air (ember), gayung, alat ukur TDS, alat ukur $\mathrm{pH}$. Sedangkan bahan utama yang digunakan dalam kediatan pengabdian kepada masyarakat ini adalah air limbah kedelai untuk diolah menggunakan modul filtrasi.

Kegiatan pengabdian pada masyarakat ini akan dibagi dalam 4 (empat) kegiatan utama, yaitu: penyuluhan sekaligus pelatihan, pendampingan dan evaluasi.

\section{HASIL DAN PEMBAHASAN}

Sebelum

pelaksanaan

kegiatan, modul filtrasi bertingkat yang dirancang diujicoba terlebih dulu menggunakan sampel limbah yang diambil dari unit pengusaha tempe. Hal ini dilakukan untuk melihat efektivitas unit filtrasi dalam mengolah air limbah. Pengambilan sampel air limbah sebanyak 21 liter dilakukan setelah mendapat persetujuan dari pemilik usaha. Air limbah kemudian dicoba untuk dilewatkan pada media filter yang disusun pada wadah akrilik (Gambar 1).

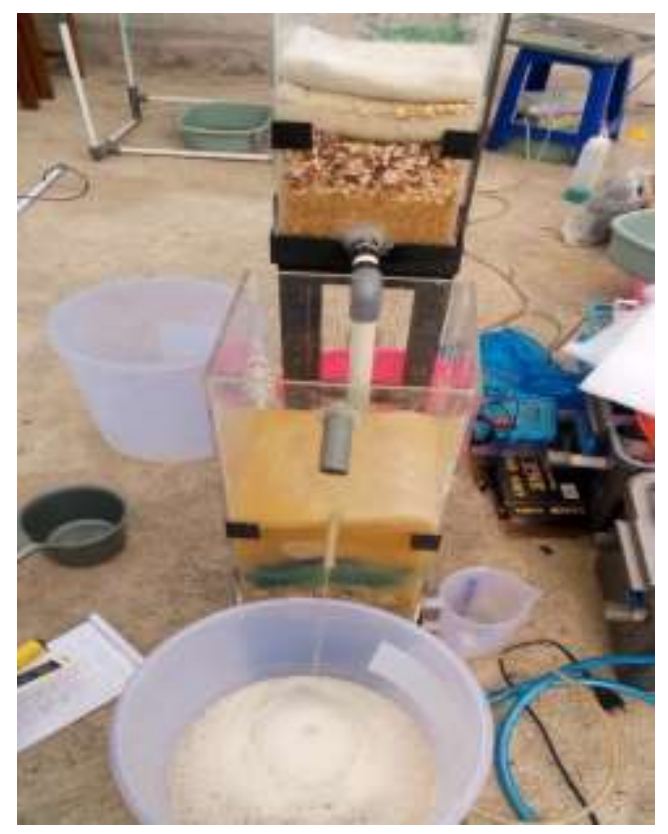

Gambar 1. Filtrasi bertingkat

Pada Gambar 2, diperlihatkan pengukuran kadar Total Dissolved Solid (TDS) dan tingkat keasaman (pH) dari sampel limbah cair produksi tempe. Sampel diukur menggunakan TDS-meter dan pH-meter yang telah dikalibrasi. Air limbah yang telah diolah kemudian diukur kembali nilai TDS dan pH-nya, kemudian dibandingkan dengan nilai sebelum pengolahan. Dari hasil pengamatan, didapatkan perubahan nilai yang tidak 
signifikan. Hal ini kemungkinan diakibatkan oleh tingginya tingkat kandungan zat pencemar yang terdapat dalam air limbah tempe.

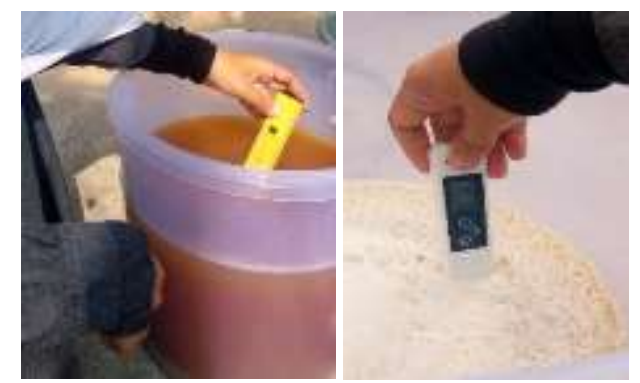

Gambar 2. Pengukuran kadar TDS dan $\mathrm{pH}$ sampel air limbah tempe

Dari hasil ujicoba ini diambil kesimpulan bahwa modul filtrasi yang dirancang belum dapat secara langsung digunakan untuk mengolah air limbah tempe. Perlu dilakukan pengolahan pendahuluan, untuk menurunkan kandungan zat organik yang terlalu tinggi pada air limbah. Melihat kondisi ini, tim mengambil keputusan untuk menggunakan air limbah jenis lain untuk pelaksanaan kegiatan pengabdian kepada masyarakat. Air yang digunakan adalah air keran yang dicampurkan dengan tanah. Selain itu, tim menyepakati untuk menambah kegiatan dengan memberikan penyuluhan mengenai pemanfaatan

Available online : http://abdiinsani.unram.ac.id Doi article : https://doi.org/10.29303/abdiinsani.v5i1.186 teknologi biopori untuk mengolah air limbah sekaligus mengolah limbat padat organik.

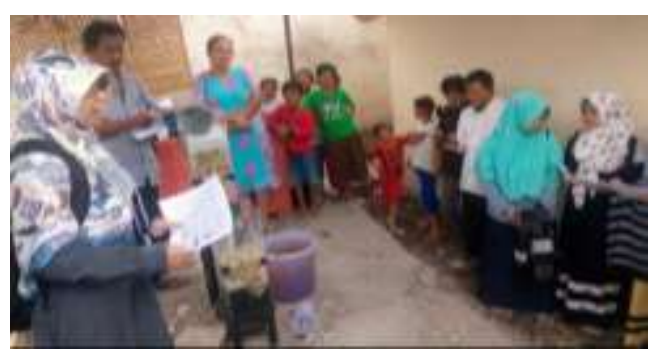

Gambar 3. Sambutan oleh ketua tim kegiatan pengabdian kepada masyarakat

Kegiatan pengabdian kepada masyarakat dilaksanakan pada 18 Oktober 2018 di salah satu sentra usaha tempe di daerah Gerisak, Kelurahan Kekalik. Kegiatan dimulai sekitar pukul 13.30 WITA diawali dengan sambutan dari ketua pelaksana (Gambar 3). Selain pemilik usaha dan para pekerja, masyarakat sekitar juga menghadiri kegiatan ini dan terlihat sangat antusias untuk menerima penyuluhan. Khususnya karena limbah yang dihasilkan cukup menggangu masyarakat akibat timbulnya bau busuk di badan air (sungai dan selokan) dan warna air menjadi semakin keruh dan menghitam. Dengan adanya kegiatan pengabdian kepada masyarakat ini, 
masyarakat berharap permasalahan limbah cair ini dapat diatasi dan terwujud lingkungan yang lebih sehat dan nyaman.

Tim kegiatan pengabdian kepada masyarakat pertama-tama menjelaskan tentang karakteristik air limbah tempe yang memiliki kandungan zat organik sangat tinggi, ditandai dengan nilai TDS yang tinggi. Kandungan zat organik yang terlalu tinggi menyebabkan media filter cepat tersumbat. Selain itu, kondisi inilah yang menyebabkan air limbah tempe cepat berbau akibat aktivitas mikroorganisme. Air limbah dengan kandungan organik tinggi ini tidak boleh langsung dibuang ke sungai karena dapat menyebabkan penurunan kualitas lingkungan.

Karena pada percobaan pendahuluan menggunakan sampel limbah cair tempe didapatkan hasil setelah diolah (dengan modul filtrasi bertingkat), air limbah tempe masih mengandung zat organik yang tinggi (penurunan zat organik tidak signifikan), tim kegiatan pengabdian kepada masyarakat menjelaskan bahwa pengolahan limbah cair tempe tidak dapat langsung dilakukan menggunakan teknologi filtrasi bertingkat. Diperlukan pengolahan pendahuluan sebelum dilakukan pengolahan dengan metode ini, dengan tujuan meningkatkan efisiensi penyisihan pencemar organik pada limbah cair tempe. Meningkatnya efisiensi penyisihan memungkinkan air limbah hasil pengolahan dibuang langsung ke lingkungan (sungai atau selokan). 

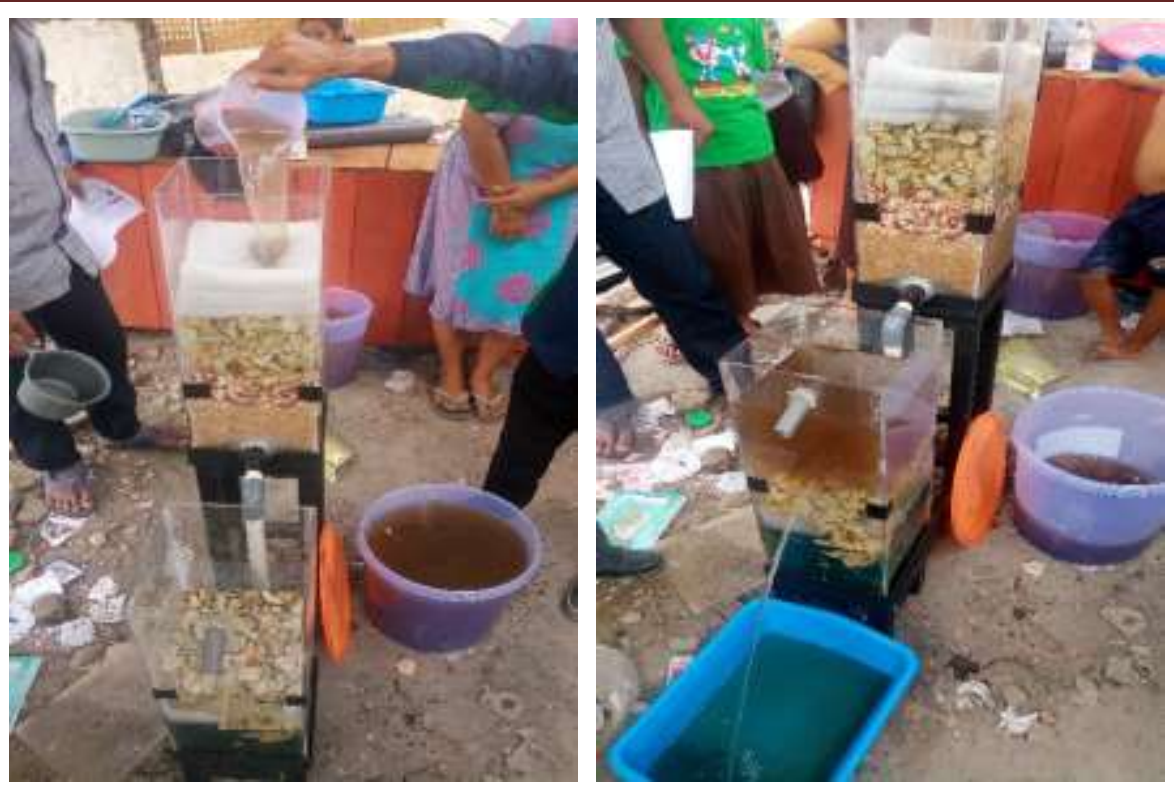

Gambar 4. Praktek pengolahan air limbah menggunakan filtrasi bertingkat

Pada kegiatan pengabdian kepada masyarakat ini selanjutnya diperlihatkan bagaimana teknologi filtrasi dapat digunakan untuk mengolah air limbah. Pada Gambar 4, sampel air limbah yang sudah disiapkan dialirkan pada wadah filtrasi A dan mengalir secara gravitasi. Selanjutnya air mengalir ke wadah filtrasi B dan naik karena prinsip hidrolika. Setelah filtrasi pertama, air yang keluar dari wadah B terlihat lebih bening, meskipun masih berwarna kecoklatan. Air ini kemudian dimasukkan kembali pada wadah filtrasi A dan mengalir kembali menuju wadah filtrasi $B$, begitu seterusnya selama beberapa kali.

Gambar 5 memperlihatkan perubahan air limbah sampel sebelum dan setelah diolah menggunakan filtrasi bertingkat, dengan beberapa kali resirkulasi. Sebelum diolah, terlihat air mengandung partikel padatan yang sangat banyak. Hal ini terlihat dari endapan berwarna hitam yang berada di bagian dasar gelas ukur. Setelah filtrasi, tidak terlihat adanya partikel padatan, warna air juga terlihat lebih bening dari sebelumnya. 


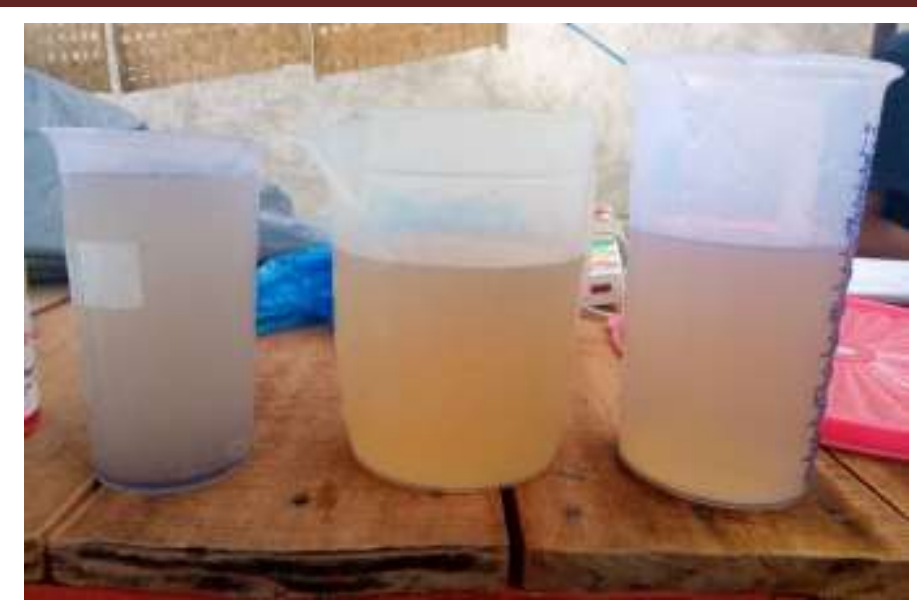

Gambar 5. Dari kiri ke kanan: air limbah sebelum diolah, air setelah diolah dua kali pengulangan, air setelah diolah 4 kali pengulan

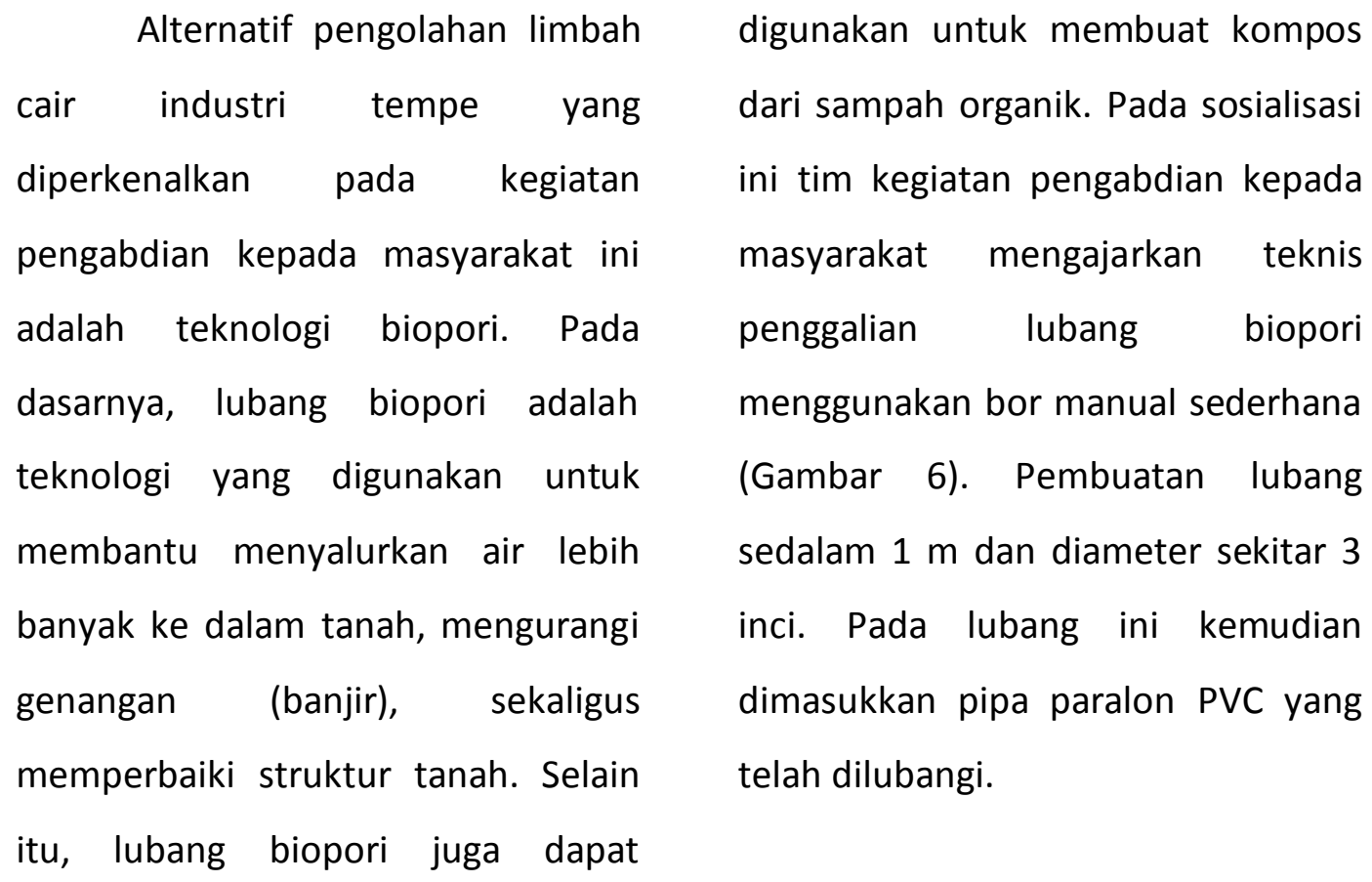



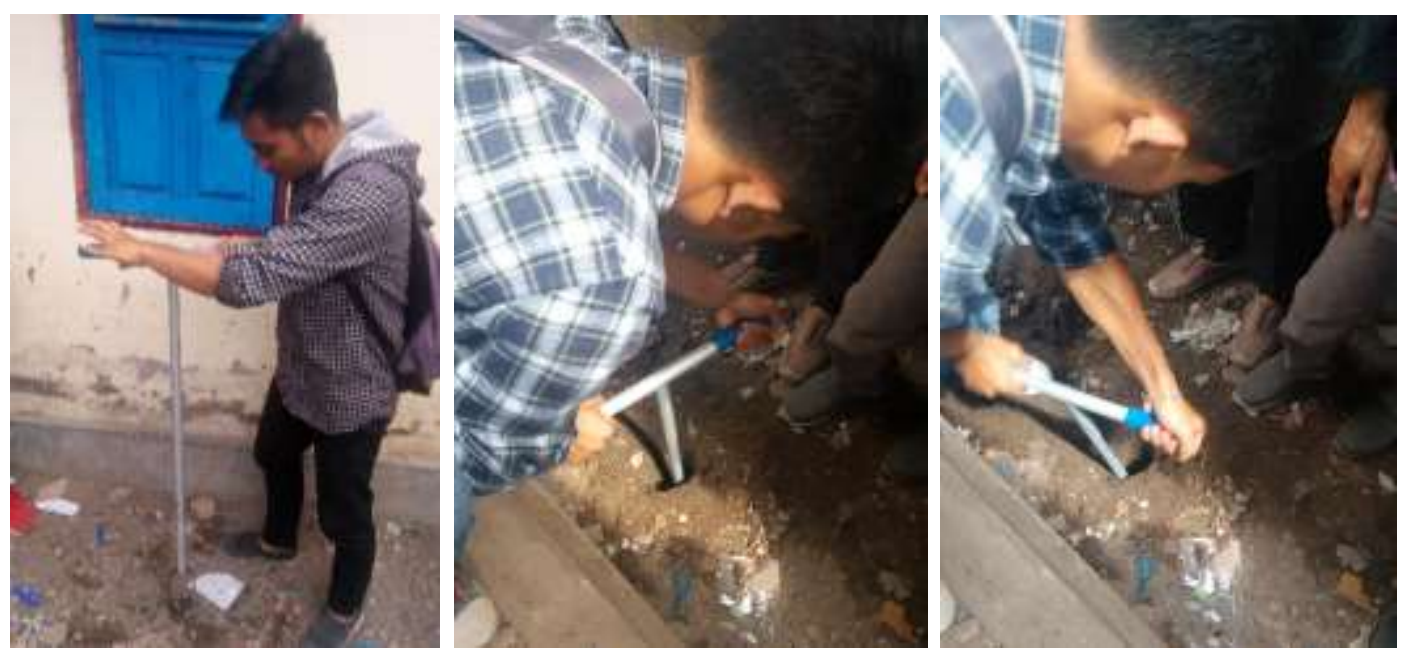

Gambar 6. Praktik pembuatan lubang biopori

Setelah lubang biopori selesai dibuat, pipa PVC sepanjang $1 \mathrm{~m}$ yang telah dilubangi sebelumnya dimasukkan ke dalam lubang, lalu diisi dengan menggunakan limbah organik (Gambar7). Dalam kegiatan pengabdian kepada masyarakat ini digunakan limbah berupa dedaunan kering. Setelah itu, pipa ditutup menggunakan tutup (dop) pipa yang juga telah dilubangi (Gambar 8). Tujuan penggunaan pipa adalah agar lubang yang terbentuk tidak mudah berubah bentuk atau runtuh. Sedangkan pipa ditutup agar lubang tidak dimasuki oleh benda lain dan mencegah orang terjatuh akibat tersandung lubang tersebut.

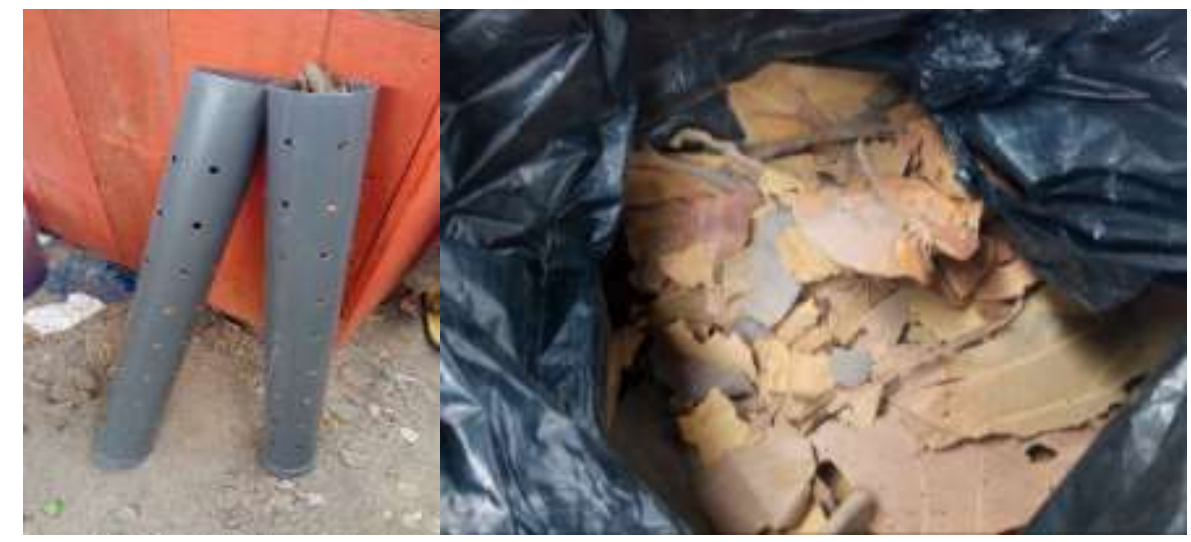

Gambar 7. Pipa PVC dan sampah organik 

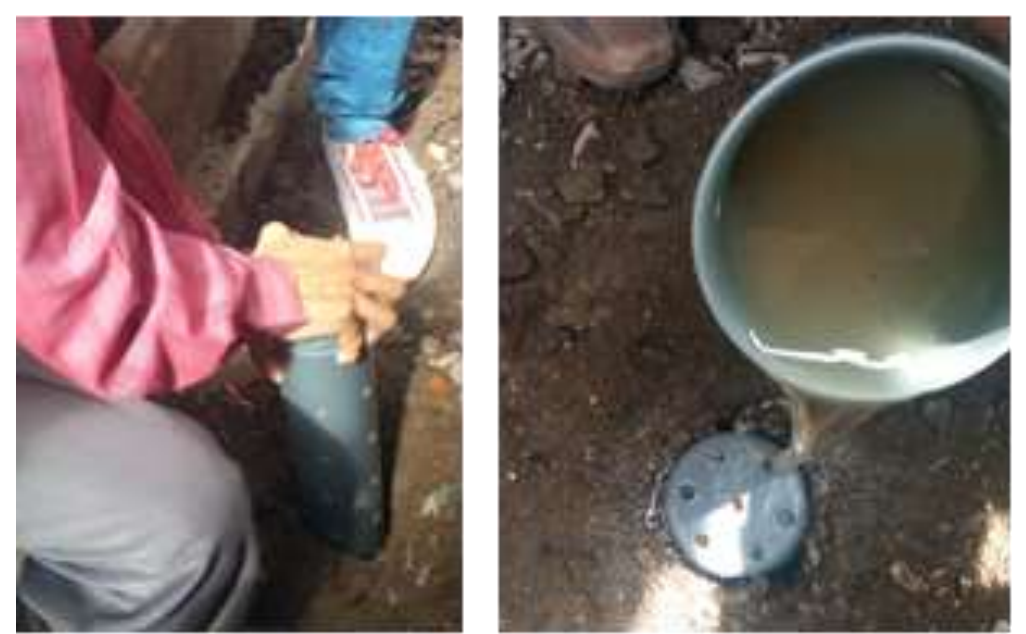

Gambar 8

pipa

PVC di lubang biopori

(kiri) dan penyiraman lubang biopori dengan air limbah (kanan)

Setelah tertanam padalubang, sebagai alternatif pengolahan air pada bagian atas lubang biopori limbah dan pengolahan limbah padat, dialirkan air limbah (Gambar 8), untuk keberadaan lubang biopori ditanggapi mempercepat aktivitas masyarakat dapat menjadi solusi dari mikroorganisme dalam mengolah masalah kurangnya daerah peresapan limbah organik di dalam lubang air di kawasan tersebut. menjadi pupuk kompos. Selain

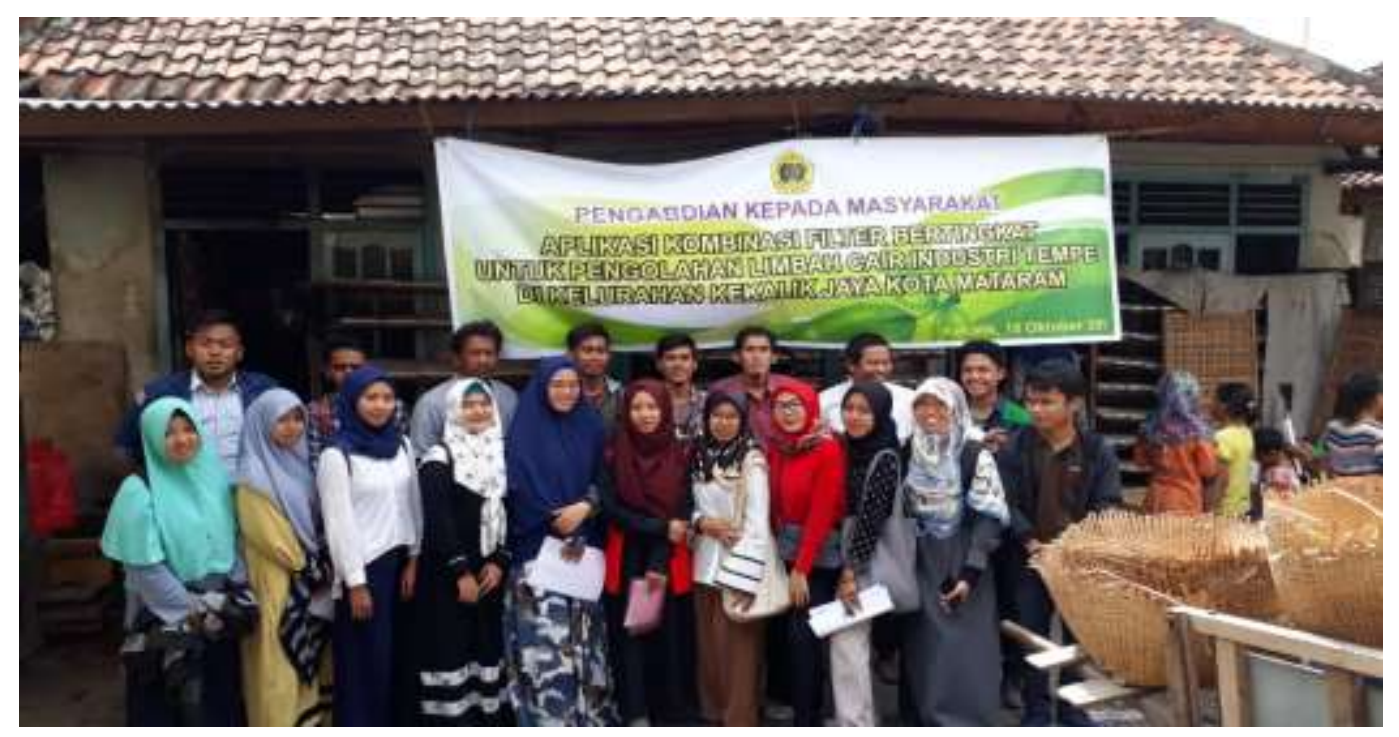

Gambar 10. Foto bersama tim kegiatan pengabdian kepada masyarakat di lokasi kegiatan 


\section{KESIMPULAN DAN SARAN}

\section{Kesimpulan}

Dari kegiatan pengabdian kepada masyarakat yang dilakukan dapat ditarik kesimpulan sebagai berikut:

1. Aplikasi teknologi filtrasi bertingkat dan lubang resapan biopori pada pengrajin tempe di Kelurahan Kekalek Jaya Mataram dapat berjalan baik. Hal ini terlihat dari antusiasme peserta dalam mengikuti kegiatan penyuluhan dan pelatihan.

2. Kesadaran masyarakat akan pentingnya pengolahan limbah, khususnya limbah cair, telah terbentuk dengan baik.

3. Masyarakat yang mengikuti kegiatan pengabdian kepada masyarakat merasa optimis kualitas lingkungan dan kesehatan masyarakat akan lebih baik dengan aplikasi teknologi yang ditawarkan pada kegiatan ini.
4. Modul filtrasi bertingkat sebagai salah satu alternatif dalam pengolahan limbah cair tempe dapat mengolah limbah cair dengan baik jika kondisinya tidak terlalu pekat. Jika terlalu pekat, diperlukan pengolahan pendahuluan terlebih dahulu.

5. Teknologi lubang resapan biopori dapat diaplikasikan sebagai salah satu solusi untuk pengolahan limbah padat dan cair, sekaligus mencegah genangan pada wilayah terkait, terutama saat musim hujan.

\section{Saran}

Saran yang dapat diberikan untuk perbaikan kegiatan pengabdian kepada masyarakat ini antara lain:

1. Uji coba pendahuluan menggunakan teknologi yang diajukan pada kegiatan pengabdian kepada masyarakat sebaiknya dilakukan jauh hari sebelum proposal disusun

2. Teknologi pengolahan limbah dan aplikasinya sebagai sumber energi alternatif dapat menjadi 
tema kegiatan pengabdian

kepada masyarakat selanjutnya.

\section{UCAPAN TERIMAKASIH}

Ucapan terimakasih kami sampaikan pada semua pihak yang mendukung sehingga kegiatan pengabdian kepada masyarakat ini dapat terselenggaranya. Kegiatan pengabdian kepada masyarakat ini terselenggara dengan Dana PNBP yang dikelola oleh Universitas Mataram dan kerjasama yang baik dari pengelola UKM Tempe Galih di Gerisak Kekalik.

\section{DAFTAR PUSTAKA}

Anonim, 2016. BLH Kota Blitar kesulitan mengatasi limbah pengrajin tahu-tempe di Kelurahan Pakunden. http://mayangkaranews.com/ blh-kota-blitar-kesulitanmengatasi-limbah-pengrajintahu-tempe-di-kelurahanpakunden/. Diakses: 5 Oktober 2018.

Kurniawan, M. W., Purwanto, P., Sudarno, S., 2013. Strategi Pengelolaan Air Limbah Sentra Umkm Batik yang Berkelanjutan di Kabupaten Sukoharjo. Jurnal IImu Lingkungan, 11 (2): 62-72.

Puspitasari, D.E., 2009. Dampak Pencemaran Air Terhadap
Kesehatan Lingkungan dalam Perspektif Hukum Lingkungan (Studi Kasus Sungai Code di Kelurahan Wirogunan Kecamatan Mergangsan dan Kelurahan Prawirodirjan Kecamatan Gondoman Yogyakarta). Mimbar Hukum, 21 (1): 23-34.

Said, N.I., dan Herlambang, A., 2003. Teknologi Pengolahan Limbah Tahu-Tempe dengan Proses Biofilter Anaerob dan Aerob. http://www.kelair.bppt.go.id/ Sitpa/Artikel/Limbahtt/limbah tt.html. Diakses: 5 Oktober 2018. 